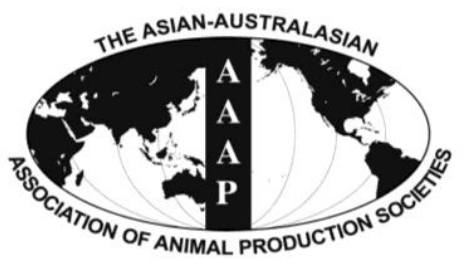

Asian-Aust. J. Anim. Sci.

Vol. 25, No. $8: 1117$ - 1123

August 2012

www.ajas.info

http://dx.doi.org/10.5713/ajas.2012.12042

\title{
Reproductive Response of Ewes Fed with Taiwan Grass Hay (Pennisetum purpureum Schum.) Supplemented with Duckweed (Lemna sp. and Spirodela sp.)
}

\author{
P. Zetina-Córdoba ${ }^{1}$, M. E. Ortega-Cerrilla ${ }^{2} *$, M. T. Sánchez Torres-Esqueda ${ }^{2}$, J. G. Herrera-Haro ${ }^{2}$, \\ E. Ortega-Jiménez ${ }^{3}$, J. L. Reta-Mendiola ${ }^{3}$ and J. Vilaboa-Arroniz ${ }^{3}$ \\ ${ }^{1}$ Universidad Politécnica de Huatusco, Huatusco, Veracruz, Mexico
}

\begin{abstract}
The effect of duckweed (DW) supplementation was evaluated on dry matter intake (DMI), presence and duration of estrus, percentage of ewes repeating estrus and pregnancy rate, as well as the concentration of progesterone $\left(\mathrm{P}_{4}\right)$ in multiparous crossbred ewes from Pelibuey, Dorper, and Katahdin breeds, fed with Taiwan grass hay (TWH). Eighteen ewes with $39.7 \pm 4 \mathrm{~kg}$ mean body weight, kept in individual pens, were randomly assigned to one of the following treatments: $\mathrm{T}_{1}: \mathrm{TWH}, \mathrm{T}_{2}$ : TWH plus $200 \mathrm{~g}$ DW, $\mathrm{T}_{3}$ : TWH plus $300 \mathrm{~g} \mathrm{DW}$. The ewes were synchronized with $40 \mathrm{mg}$ fluorogestone acetate (FGA) and 400 UI equine chorionic gonadotropin (eCG). Data were analyzed as a completely randomized design using the GLM procedure. DW supplementation had no effect on dry matter intake ( $p>0.05$ ); however, a slight decrease of TWH intake was observed as DW supplementation increased. No differences $(p>0.05)$ were found in the beginning of estrus, percentage of ewes presenting it, its duration, or pregnancy rate. There were no differences $(p>0.05)$ on $\mathrm{P}_{4}$ concentration among treatments, or treatment $\times$ period interaction $(p>0.05)$. However the period was significant $(\mathrm{p}<0.01)$, since the $\mathrm{P}_{4}$ levels increased as time increased after the removal of the FGA device and eCG application. (Key Words: Duckweed, Taiwan Grass, Multiparous Ewes)
\end{abstract}

\section{INTRODUCTION}

In tropical zones, where day (light hours) variation is minimum, sheep are not seasonal, in contrast to breeds from other latitudes where annual variation in day length is greater (Martinez et al., 2001). Nevertheless, factors such as high temperatures and lack of feed can limit their sexual activity for some months, mainly the first months of the year (Castillo et al., 1972; Cruz et al., 1994). Several studies have proven that nutrition constitutes one of the factors that greatly influence the reproductive processes of male and female domestic animals (Martin and Walkden-Brown, 1995; Leroy et al., 2005). Supplementing the ewes with nutritious feed before mating, known as flushing, has been

\footnotetext{
* Corresponding Author: M. E. Ortega-Cerrilla. Tel: $+52-5558$ 045979, Fax: +52-5558045979, E-mail: meoc@colpos.mx

2 Colegio de Postgraduados, Ganaderia, Carretera MexicoTexcoco km 36.5, 56230 Montecillo, Estado de Mexico, Mexico.

${ }^{3}$ Colegio de Postgraduados, Campus Veracruz, Carretera XalapaVeracruz km 88.5, Predio Tepetates, Municipio Manlio Fabio Altamirano, 91690 Veracruz, Mexico.

Submitted Jan. 22, 2012; Accepted Apr. 1, 2012; Revised May 10, 2012
}

used to increase ovulation ratio and embryo survival (Johnson et al., 1990). The effects of nutrition on follicle development and ovulation ratio can potentially be mediated by changes in the circulation of metabolites (glucose, amino acids, etc.), gonadotropins (LH and FSH), metabolic hormones, or a combination of these factors (Rhind, 1992). To make up for the protein deficiency of tropical grasses (5 to 7\%), some species of aquatic plants have been used as feed supplement for ruminants (Gallego et al., 1994). Duckweed contains 20 to $25 \%$ protein, which can be increased, through the use of organic fertilizers, up to $45 \%$, and thus can be utilized to increase the nutritional value of the diet (Huque et al., 1996; Cheng and Stomp, 2009), since it is highly digestible given its low lignin content (Castillo et al., 2005). On the other hand, Taiwan grass (Pennisetum purpureum) is one of the most important tropical forages and is widely spread in tropical and subtropical regions of the world (Zhang et al., 2011). The objective of this work was to determine the effect of duckweed supplementation in Taiwan grass hay based diets on some reproductive variables of crossbred sheep from Pelibuey, Dorper, and Katahdin breeds. 


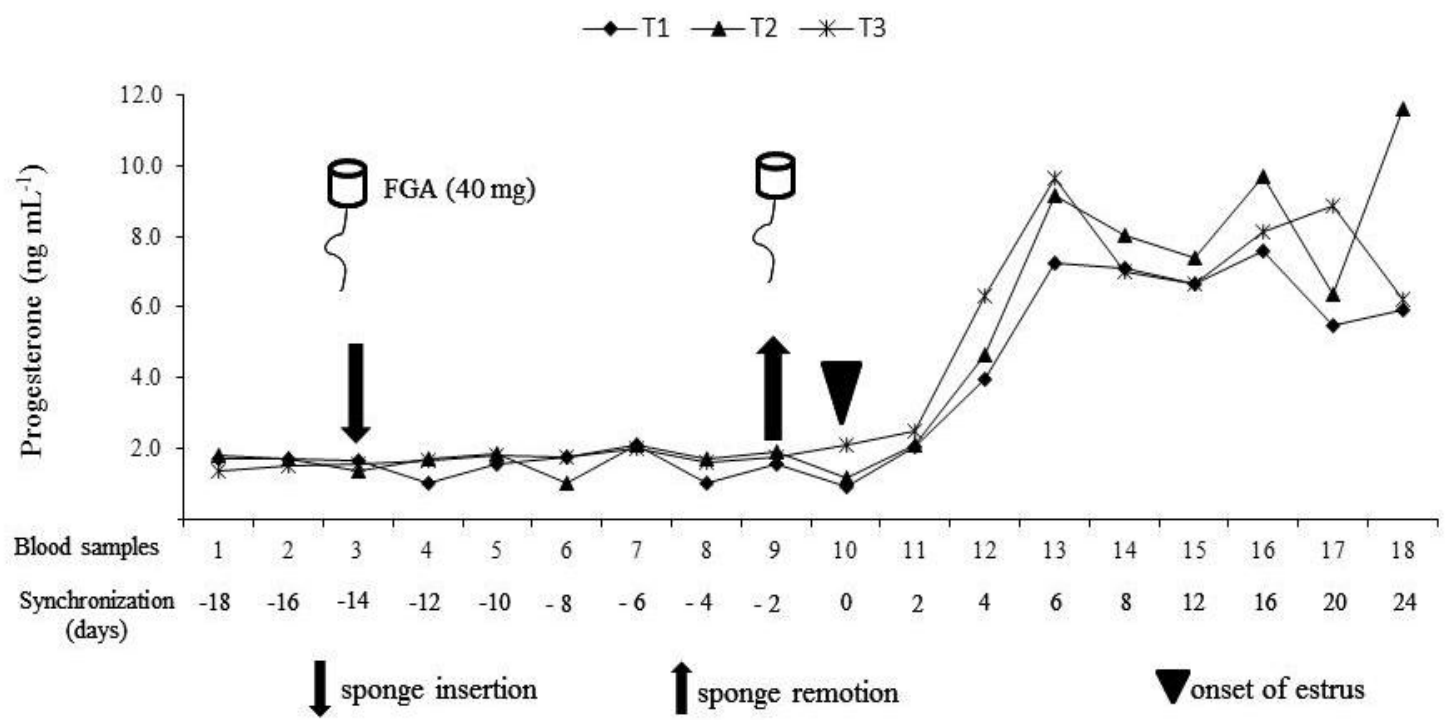

Figure 1. Progesterone concentration and synchronization protocol with intravaginal sponges. n: 6 .

\section{MATERIALS AND METHODS}

Experimental site, animals, and synchronization protocol

In this study, 18 multiparous, crossbred ewes from Pelibuey, Dorper, and Katahdin breeds were used (39.7 44.0 $\mathrm{kg}$ ), with a body condition from 3 to 3.5 in a 1 to 5 scale (Cottle, 1991), and similar characteristics regarding size and age. They were kept in individual pens, with free access to water and mineral salts. Before beginning the experiment, they were dewormed and vaccinated. The ewes were synchronized with intravaginal sponges impregnated with $40 \mathrm{mg}$ fluorogestone acetate (FGA, Chronogest ${ }^{\mathrm{TM}}$ ) and an intramuscular application of 400 UI equine chorionic gonadotropin (eCG, Folligon ${ }^{\mathrm{TM}}$ ) at the moment of removing the sponges, which were placed $94 \mathrm{~h}$ after supplying the diets and removed $12 \mathrm{~d}$ later.

\section{Experimental diets, chemical analysis and experimental design}

Taiwan grass hay (TWH) (50 d after regrowth) used as a base diet, was supplemented with sundried duckweed (DW) (Lemna sp. and Spirodela sp.) to improve the protein content of the diet. DW was fed at 7:00 h, and TWH was given ad libitum at 8:00 and 16:00 h. Ewes were randomly assigned to the following treatments $(n=6): T_{1}$ : TWH (control), $\mathrm{T}_{2}$ : TWH plus $200 \mathrm{~g} \mathrm{DW}, \mathrm{T}_{3}$ : TWH plus $300 \mathrm{~g}$ DW.

TWH and DW were analyzed for dry matter (DM), organic matter $(\mathrm{OM})$ and crude protein $(\mathrm{CP})$ according to the AOAC (2005). Neutral detergent fiber (NDF) and acid detergent fiber (ADF) by Van Soest et al. (1991).

\section{Evaluated variables}

Dry matter, crude protein intake and progesterone concentration in plasma: Dry matter intake (DMI) and crude protein intake (CPI) were measured through the difference between offered and rejected DM or CP $\left(\mathrm{g}\right.$ anim $^{-1}$ $\left.\mathrm{d}^{-1}\right)$. To determine the progesterone concentration $\left(\mathrm{P}_{4}\right), 5 \mathrm{ml}$ of blood were individually collected through jugular puncture, centrifuged at 3,000 rpm for $15 \mathrm{~min}$ and the plasma obtained was kept at $-4^{\circ} \mathrm{C}$. The first and second samples were collected $94 \mathrm{~h}$ and $48 \mathrm{~h}$, respectively, before synchronization, the third sampling at the moment of inserting the sponges, and then every third day. The last four samples were collected every four days, with a total of 18 samplings (Figure 1). To quantify $\mathrm{P}_{4}$, the tube enzymatic immunoassay (EIA) methodology (Reimers, 1984) was used.

\section{Estrus detection, ewes repeating estrus and pregnancy diagnosis}

Estrus detection began $12 \mathrm{~h}$ after removing the sponges and every $2 \mathrm{~h}$ for $20 \mathrm{~min}$, using 4 rams with aprons. The beginning was considered from the moment the ewe allowed the ram to mate, finalizing when it was no longer receptive. The ewes were mated twice, at the beginning of estrus and $12 \mathrm{~h}$ later. The rams were rotated every four services to avoid exhaustion and allow semen production.

To detect the return to estrus, $14 \mathrm{~d}$ after the last day of mating, the ewes were exposed to 4 rams, considering that the sexual cycle of sheep is $17 \pm 3 \mathrm{~d}$. The same procedure was used to detect estrus. The pregnancy diagnosis was done $21 \mathrm{~d}$ after the last day of mating with the animal standing and using a transabdominal technique with a frequency of 3.0 MHz (Memon and Ott, 1979). A Digital Veterinary Ultrasound Imaging System, model CTS-3300V, 
SIUI brand equipment was used.

\section{Statistical analysis}

Data on DMI, CPI, onset and beginning of estrus, were analyzed as a completely randomized design using the GLM procedure (SAS, 2000). Initial weight was used as a covariate for DMI and CPI. Data on $\mathrm{P}_{4}$ was analyzed using the MIXED procedure of SAS. Percentage of estrus, ewes that repeated estrus, and rate of pregnant ewes were analyzed using Chi-square test and Fisher exact test.

\section{RESULTS AND DISCUSSION}

\section{Chemical composition of forages}

Table 1 shows the chemical composition of TWH and DW. The results agree with those reported by Kozloski et al. (2006) and Da Silva et al. (2007) regarding TWH; however, $\mathrm{CP}$ content differs from the results obtained by Tessena and Baars (2004). This could be due to type of fertilization used on the graminea. Regarding DW, the values obtained coincide with those found by Huque et al. (1996) and Olorunfemi et al. (2006).

\section{Dry matter and crude protein intake}

DMI was similar for all three treatments $(\mathrm{p}>0.05)$ (Table 2); although there was a slight decrease in the intake of the base diet as DW was supplemented. Similar results were obtained by Aregheore (2006) who supplemented copra cake in Taiwan grass diets. Kahindi et al. (2007) reported a decrease in Taiwan grass intake when supplementation with Madras thorn (Pithecellobium dulce) increased. Abdulrazak et al. (1996) observed a decrease in the intake of Taiwan
Table 1. Chemical composition of Taiwan grass hay and duckweed

\begin{tabular}{lrc}
\hline & TWH & DW \\
\hline \% Dry matter & 86.80 & 87.50 \\
As \% of dry matter & & \\
Organic matter & 87.47 & 82.40 \\
Crude protein & 9.90 & 23.12 \\
NDF & 64.30 & 47.60 \\
ADF & 37.65 & 25.73 \\
Ash & 12.53 & 17.60 \\
\hline
\end{tabular}

$\mathrm{TWH}=$ Taiwan grass hay; DW = Duckweed .

grass when supplemented with increasing levels of gliricidia (Gliricidia sepium), which they attributed to legume's volume. Supplementation with DW caused a slight decrease in the intake of TWH, although total DMI among treatments was not different ( $p>0.05$ ); however, this could be justified by the restriction of DW, which was not fed ad libitum. On the other hand, fertilization of the DW with ovine manure could have affected taste and smell, which in turn decreased DMI, and probably the presence of antinutritional factors in DW (Bairagi et al., 2002; Kalita et al., 2007). Supplementation with DW increased intake of $\mathrm{CP}(\mathrm{p}<0.05)$, where $\mathrm{T}_{3}$ was different from $\mathrm{T}_{2}$ and $\mathrm{T}_{1}$ (Table 2). An increase in the intake of $\mathrm{CP}$ was observed when supplementing with $300 \mathrm{~g} \mathrm{DW}(\mathrm{p}<0.01)$, with no difference between $\mathrm{T}_{1}$ and $\mathrm{T}_{2}$. Daily CP intake in all three treatments was higher than the recommended by NRC (1985).

\section{Onset, beginning and duration of estrus}

Table 3 shows the beginning of estrus after removing

Table 2. Dry matter and crude protein intake of ewes fed Taiwan grass hay alone or supplemented with duckweed

\begin{tabular}{|c|c|c|c|c|c|c|c|c|}
\hline & \multicolumn{2}{|c|}{$\mathrm{T}_{1}$} & \multicolumn{2}{|c|}{$\mathrm{T}_{2}$} & \multicolumn{3}{|c|}{$\mathrm{T}_{3}$} & \multirow{2}{*}{ SEM } \\
\hline & TWH & TWH & DW & Total & TWH & DW & Total & \\
\hline Dry matter intake $\left(\mathrm{g} \mathrm{d}^{-1}\right)$ & $1,207.30^{\mathrm{a}}$ & 917.80 & 193.20 & $1,111.00^{\mathrm{a}}$ & 890.50 & 295.30 & $1,185.80^{\mathrm{a}}$ & 53.5 \\
\hline Dry matter intake $\left(\mathrm{g} \mathrm{kg}^{-1} \mathrm{BW}^{0.75} \mathrm{~d}^{-1}\right)$ & $77.03^{\mathrm{a}}$ & 59.40 & 12.50 & $72.10^{\mathrm{a}}$ & 54.40 & 18.20 & $72.70^{\mathrm{a}}$ & 1.6 \\
\hline Dry matter intake (\% BW) & $3.07^{\mathrm{a}}$ & & & $2.89^{\mathrm{a}}$ & & & $2.87^{\mathrm{a}}$ & 0.1 \\
\hline Crude protein $\left(\mathrm{g} \mathrm{d}^{-1}\right)$ & $119.53^{\mathrm{a}}$ & 92.42 & 44.70 & $137.12^{\mathrm{a}}$ & 89.20 & 68.50 & $157.52^{\mathrm{b}}$ & 5.3 \\
\hline Crude protein intake $\left(\mathrm{g} \mathrm{kg}^{-1} \mathrm{BW}^{0.75} \mathrm{~d}^{-1}\right)$ & $7.62^{\mathrm{a}}$ & 2.87 & 5.88 & $8.75^{\mathrm{b}}$ & 4.26 & 5.42 & $9.68^{\mathrm{c}}$ & 0.2 \\
\hline
\end{tabular}

$\overline{a, b, c}$ Values in the same row with similar superscript are similar ( $>0.05)$. TWH $=$ Taiwan grass hay; DW $=$ Duckweed.

$\mathrm{SEM}=$ Standard error of mean. $\mathrm{n}: 6$.

Table 3. Estrus behavior and pregnant rate

\begin{tabular}{|c|c|c|c|c|}
\hline \multirow{2}{*}{ Event } & $\mathrm{T}_{1}$ & $\mathrm{~T}_{2}$ & $\mathrm{~T}_{3}$ & \multirow{2}{*}{ SEM } \\
\hline & TWH & TWH+200 g DW & TWH+300 g DW & \\
\hline Beginning of estrus (h) & $35.72^{\mathrm{a}}$ & $34.84^{\mathrm{a}}$ & $42.95^{\mathrm{a}}$ & 4.05 \\
\hline Onset of estrus (\%) & 83.33 & 83.33 & 100 & \\
\hline Duration of estrus (h) & $31.34^{\mathrm{a}}$ & $30.00^{\mathrm{a}}$ & $31.85^{\mathrm{a}}$ & 0.78 \\
\hline Return to estrus & 0 & 0 & 0 & \\
\hline Pregnant ewes (\%) & 80 & 80 & 83 & \\
\hline
\end{tabular}

a Values in the same row with similar superscript are similar (p>0.05). TWH = Taiwan grass hay; DW = Duckweed. SEM = Standard error of mean. $\mathrm{n}: 6$. 
the synchronization device. No difference was found on the beginning of estrus ( $p>0.05)(35.72,34.83$, and $42.95 \mathrm{~h}$ for $\mathrm{T}_{1}, \mathrm{~T}_{2}$, and $\mathrm{T}_{3}$, respectively). These results coincide with Molina et al. (2005), who reported an interval in the onset of estrus of 32 to $36 \mathrm{~h}$, but differ from Camacho-Ronquillo et al. (2008), who observed a beginning of estrus between 21.4 and $24.2 \mathrm{~h}$, and attribute the early appearance of estrus to the application of eCG two days before removing the FGA sponges. In the present study, eCG was applied at the moment of removing the sponges and most estrus appeared in the first $48 \mathrm{~h}$, which coincides with Mendoza (2008) and Fukuy et al. (1999) when using a similar synchronization protocol.

DW supplementation did not affect the percentage of estrus appearance $(\mathrm{p}>0.05)$ (Table 3$)$. In $\mathrm{T}_{1}$ and $\mathrm{T}_{2}$, one ewe did not respond to the synchronization protocol; however, they were not different $(\mathrm{p}>0.05)$ from $\mathrm{T}_{3}$. A deficient $\mathrm{P}_{4}$ absorption from the intravaginal sponges could have been the cause of this lack of response to synchronization (Kenji et al., 2004); when the device with $\mathrm{P}_{4}$ was inserted, the ewes were at different stages of the oestral cycle, which could have caused a variation in the duration of endogenous $\mathrm{P}_{4}$ secretion. According to Leyva et al. (1998), the changes resulting from the combination of exogenous and endogenous $\mathrm{P}_{4}$ can cause alterations in the follicular dynamics and variations in the appearance of estrus, once the device is removed. The variations in the ovarian response seem to be due to the differences in the degree of follicular maturation, presence of ovulatory follicles, non ovulatory follicles, and subfunctional corpora lutea (Liu et al., 2007).

DW supplementation had no effect on the number of ewes presenting estrus, nor on the duration of these ( $>0.05$ ) (Table 3). Gordon (1997) and Fernandez et al. (1997) point out that estrus duration in sheep varies from 24 to $48 \mathrm{~h}$, can increase by up to $50 \%$ in ewes with multiple ovulations (Camacho-Ronquillo et al., 2008), or decrease by half when the ewes are kept with the ram, compared to ewes where estrus is detected with the ram every $2 \mathrm{~h}$ (Gonzalez et al., 2000). The results obtained in the appearance of estrus (Table 3) were within the 24 to $48 \mathrm{~h}$, and coincide with Mazzarri et al. (1976), but differ from Cordova-Izquierdo et al. (1999) who mention a $26 \mathrm{~h}$ duration, and attribute it to the period of non reproductive season, since in the season of ovarian cyclicity the duration can regularly reach $30 \mathrm{~h}$. Nevertheless, Camacho-Ronquillo et al. (2008) report estrus duration of up to $60 \mathrm{~h}$, which they attribute to a greater number of ovulatory follicles, from the effect of applying eCG two days before removing the progestagen. Navarrete-Sierra et al. (2008) used diets with high quality protein in ewes synchronized with FGA for superovulatory treatment based on ovine follicle stimulating hormone, and observed an increase in the ovulation rate and secretion of $\mathrm{P}_{4}$, as well as an extension of estrus through the lengthening of the midcycle lifespan of the corpus luteum.

\section{Percentage of ewes repeating estrus}

Using the same protocol to detect estrus, no ewe returned to estrus. Lozano et al. (2003) mention that low energy diets during the embryo development stage increases in vitro production of $\mathrm{PGF}_{2 \alpha}$; which could cause luteolisis and embryonic death, which causes a return to estrous cycles from the inability of maintaining gestation. Martinez (1999) reports that $89.4 \%$ of the ewes did not return to estrus (17 out of 19 animals), and attributes it to the fact that the sanitary and nutritional conditions were adequate. Mendoza (2008) points out that only one ewe returned to estrus, and mentions that this was due to the fact that the nutrition supplied was adequate. DW supplementation did not affect the return to estrus, which suggests that the ewes were able to obtain enough energy and protein from the diet to sustain gestation and avoid return to estrus.

\section{Pregnancy rate}

DW supplementation had no influence $(p>0.05)$ on gestation percentage (Table 3 ). The pregnancy diagnosis showed that ewes with $\mathrm{T}_{1}$ and $\mathrm{T}_{2}$ had $80 \%$ pregnancy, while those with $\mathrm{T}_{3}$ had $83 \%$. Protein supplementation before mating, mainly with amino acids like lysine and methionine, can increase fertility, since several hormones (hypothalamic, pituitary, and ovarian) are of protein origin (Mitchell et al., 1998; Bell and Bauman, 2006). The explanation to the response obtained in this study could be due to the high rumen CP degradability of DW (Khan et al., 2002), which decreases the supply of amino acids; and although an increase in the intake of this nutrient stimulates the ovulation rate, the effect is more evident when the intake prior to flushing is at maintenance level or slightly below it (Fletcher, 1981). However, in ruminants, reproduction has been directly associated with energy availability, decreasing the ovulation rate when this nutrient is reduced in the diet (Wathes et al., 2007). Energy and protein supply influence the ovulation rate, but in order to reach the maximum effect, an increase of both nutrients may be needed (Fernandez et al., 2007). Energy or protein flushing does not always allow for homogeneous responses to exogenous stimuli of multiple ovulation (Lozano et al., 2003). The obtained results (81\% mean in all 3 treatments) are similar to those reported by Camacho-Ronquillo et al. (2008), who observed $85.7 \%$ pregnancy with a diet based on oats and alfalfa, as well as a commercial concentrate with $16 \%$ protein, ad libitum.

\section{Progesterone concentration}

Supplementation did not affect $\mathrm{P}_{4}$ concentration $(p>0.05)$. However, the sampling period was different 
$(p<0.01)$, although the treatment $\times$ period interaction showed no differences $(p>0.05) . \quad P_{4}$ concentrations increased significantly $(\mathrm{p}<0.01)$ starting on $\mathrm{d} 4$ of the sampling (Figure 1), approximately $4 \mathrm{~d}$ after removing the sponge impregnated with FGA and the application of eCG, when the corpus luteum finished its formation and increase $\mathrm{P}_{4}$ secretion as it matures, since it is necessary to maintain sheep pregnancy (Bartlewski et al., 1999). This coincides with the reports by Uribe-Velasquez et al. (2008) and Mendoza (2008), who also synchronized with FGA and eCG. It is considered that circulating levels of $\mathrm{P}_{4}$ greater than $2 \mathrm{ng} \mathrm{ml}^{-1}$ are indicative that the luteal tissue is active and there is a probable pregnancy (Restall et al., 1990); however, even if these levels are detected, some ewes do not reach lambing since they can develop pyometra, condition in which the corpus luteum remains active (Ortega, 1997), or because of embryonic death, which occurs in 2 to $8 \%$, even up to $20 \%$, of the cases under normal conditions (Fowler and Wilkins, 1984; Bretzlaff et al., 1993). $\mathrm{P}_{4}$ concentration in the blood for early diagnosis of pregnancy is a technique used 19 to $23 \mathrm{~d}$ post-service in ruminants (Ortega-Pacheco et al., 1999). High $\mathrm{P}_{4}$ levels suggest the presence of an active corpus luteum, which is compatible with pregnancy (Matsas, 1993). Under this premise, it is probable that all the ewes in heat and mated were pregnant in the last sampling ( $21 \mathrm{~d}$ post-service), considering that the $\mathrm{P}_{4}$ concentrations were above $2 \mathrm{ng} \mathrm{ml}^{-1}$.

However, Gonzalez and Botero (1983) and OrtegaPacheco et al. (1999) report a low efficiency of ultrasonography to detect pregnancy at $21 \mathrm{~d}$, regardless of the technique used, since the size of the fetal sacks is too small, and detection may be hindered by diverse factors such as corporal condition, fasting, and experience of the operator, then they consider $\mathrm{P}_{4}$ concentrations in plasma a more reliable test. In this research, detection of pregnancy was performed $24 \mathrm{~d}$ post-service. The factors previously mentioned could explain that pregnancy was not detected in some ewes with a probability of presenting it, given that they had $\mathrm{P}_{4}$ concentrations above $2 \mathrm{ng} \mathrm{ml}^{-1}$.

$\mathrm{P}_{4}$ concentration in the three samplings before synchronization $(d-16)$ was different $(p<0.05)$ to the $P_{4}$ concentration obtained in the samplings collected on day 4 which was at the time when the corpus luteum was finishing its formation and day 21 when pregnancy was detected. However, it was not different $(p>0.05)$ from the samplings corresponding to the beginning of estrus ( $d 0) . P_{4}$ secretion can be affected by the reproductive stage of the ewes; however, the corpus luteum capability to secrete $\mathrm{P}_{4}$ is also a factor associated with $\mathrm{P}_{4}$ concentration in the blood. Evans and Robinson (1980) mention that it is possible to establish the existence of a direct relationship among eCG doses, corpus luteum, ovulation rate, and $\mathrm{P}_{4}$ concentrations in plasma in ewes previously treated with this progestagen.

\section{CONCLUSIONS}

The results obtained showed that DMI and CPI were not affected by DW supplementation. However, a slight decrease in TWH intake was observed as the DW supplementation levels increased. The number of ewes presenting estrus, the beginning and duration of estrus, pregnancy rate and $\mathrm{P}_{4}$ concentration in plasma were not affected by DW supplementation in diets based on TWH.

\section{ACKNOWLEDGEMENT}

The authors would like to thank Research Line 11 "Agricultural, Animal, Forestry, Aquaculture, and Fishing Production Systems" of the Colegio de Postgraduados for its financial support.

\section{REFERENCES}

Abdulrazak, S. A., R. W. Muinga, W. Thorpe and E. R. Ørskov. 1996. The effects of supplementation with Gliricidia sepium or Leucaena leucocephala forage on intake, digestion, and liveweight gains of Bos Taurus $\times$ Bos indicus steers offered napier grass. Anim. Sci. 63:381-388.

AOAC. 2005. Association of official analytical chemists. Official methods of analysis of the AOAC. 18th ed. AOAC. Arlington, VA, USA.

Aregheore, E. M. 2006. Utilization of concentrate supplements containing varying levels of copra cake (Cocos nucifera) by growing goats fed a basal diet of napier grass (Pennisetum purpureum). Small Rum. Res. 64:87-93.

Bairagi, A., K. S. Ghosh, S. K. Sen and A. K. Ray. 2002. Duckweed (Lemna polyrhiza) leaf meal as a source of feedstuff in formulated diets for rohu (Labeo rohita Ham.) fingerlings after fermentation with a fish intestinal bacterium. Bioresour. Technol. 85:17-24.

Bartlewski, P. M., A. P. Beard and C. Rawlings. 1999. An ultrasonographic study of luteal function in breeds of sheep with different ovulation rates. Theriogenology 52:115-130.

Bell, A. W. and D. E. Bauman. 2006. Regulation of amino acid metabolism in dairy and beef cattle. In: 21 st Annual Southwest Nutrition and Management Conference. Tempe, Arizona. 3444, EUA.

Bretzlaff, K., J. Edwards, D. Forrest and L. Nuti. 1993. Ultrasonographic determination of pregnancy in small ruminants. Vet. Med. 1:12-19.

Camacho-Ronquillo, J. C., J. C. Rodríguez-Castillo, J. E. Hernández-Hernández, A. Pró-Martínez, C. M. Becerril-Pérez and J. Gallegos-Sánchez. 2008. Características reproductivas de ovejas Pelibuey sincronizadas e inducidas a la pubertad. Arch. Latinoam. Prod. Anim. 16:18-24.

Castillo, M., A. Padilla, J. Suniaga, A. Betancourt and E. Marcano. 2005. Análisis de Lemna sp. del Lago de Maracaibo para su eventual utilización en la alimentación de rumiantes. Agricultura Andina 10:3-8.

Castillo, R. H., Z. M. Valencia and J. M. Barruecos. 1972. Comportamiento reproductivo del borrego Tabasco mantenido 
en clima tropical y subtropical. I. Índice de fertilidad. Tec. Pec. Mex. 20:52-56.

Cheng, J. J. and A. M. Stomp. 2009. Growing duckweed to recover nutrients from wastewaters and for production of fuel ethanol and animal feed. Clean:Soil Air Water 37:17-26.

Córdova-Izquierdo, A., G. Ruiz-Lang, J. Saltijeral-Oaxaca, J. F. Pérez-Gutiérrez and T. Degefa-Dadi. 1999. Inducción y sincronización de celos en ovejas criollas anéstricas estacionales con esponjas vaginales impregnadas con FGA y PMSG inyectable. Arch. Zootec. 48:437-440.

Cottle, D. J. 1991. Feeding. In: Australian Sheep and Wool Handbook. Inkata Press, Melbourne, Australia. pp. 331-372.

Cruz, L. C., S. B. Fernández and R. H. Pérez. 1994. Variaciones estacionales en presentación de ovulación, fertilización y sobrevivencia embrionaria en ovejas Tabasco en el trópico húmedo. Vet. Mex. 25:23-27.

Da Silva, M. J. A., S. L. M. Bonnecarrére, Y. I. Koslozki, L. L. Dorneles, L. M. Trevisan, R. M. Vizzotto and J. R. L. Cadorin. 2007. Dwarf elephant grass hay (Pennisetum purpureum Schum. cv Mott) digestion by sheep at different levels of intake. Cienc. Rural. 37:482-487.

Evans, G., and T. J. Robinson. 1980. The control of fertility in sheep: endocrine and ovarian responses to progestagen-PMSG treatment in the breeding season and in anoestrus. J. Agric. Sci. 94:69-88.

Fernández, A., D. Baru, V. López, M. M. Rey, M. Urioste and M. Villegas. 1997. Studies on the duration of oestrus in the ewe outdoors. Producción Ovina. 10:53-62.

Fernández, D., D. Formoso, O. Casco, M. E. Delgado, A. P. García, and W. Ibañez. 2007. Efecto de un flushing focalizado utilizando Lotus uliginosus cv Maku, bloques protéicos y expeler de soja sobre la tasa ovulatoria y fecundidad de ovejas Corriedale. Arch. Med. Vet. 10:33-42.

Fletcher, Y. C. 1981. Effects of energy and protein intake on ovulation rate associated with the feeding of Lupin grain to Merino ewes. Aust. J. Agric. Res. 32:79-87.

Fowler, D. G. and J. G. Wilkins. 1984. Diagnosis of pregnancy and number of fetuses in sheep by real-time ultrasound imaging I. Effects of number of fetuses, stage of gestation, operator and breed of ewe on accuracy of diagnosis. Livest. Prod. Sci. 11:137-450

Fukuy, Y., N. Ishikawa, R. Ishida and T. Ogosi. 1999. Comparison of fertility of estrous synchronized ewes with four different intravaginal devices during the breeding season. J. Reprod. Dev. 45:335.343.

Gallego, L., R. Berbabéu and P. Molina. 1994. Producción de leche: factores de variación. In: Ganado ovino. Raza Machenga (Ed. L. Gallego, A. Torres and G. Caja). Ediciones Mundi-Prensa. Madrid. p. 430.

González, R. G. A., M. Vázquez, O. Duarte and R. A. González. 2000. Efecto del morueco y la época de empadre sobre el comportamiento reproductivo en ovejas Pelibuey y Blackbelly. En: XXVIII Reunión Nacional de la Asociación Mexicana de Producción Animal. Tapachula, Chiapas. p 157. México.

González, S. C. and H. O. Botero. 1983. Aplicación de la ecografía de ultrasonido en el diagnóstico precoz de la gestación de la cabra. 9a. Reunión de la Asoc. Latinoam. Produc. Anim. Venezuela. 28-35.

Gordon, I. R. 1997. Controlled reproduction in sheep and goats.
Cab. International. (2) Ireland. p. 450

Huque, K. S., S. A. Chowdhury and S. S. Kibria. 1996. Study on the potentiality of duckweeds as a feed for cattle. Asian-Aust. J. Anim. Sci. 9:133-134

Johnson, W. L., N. N. Barros and E. R. de Oliveira, 1990. Supplemental feed resources and their utilization by hair sheep. In: Hair Sheep Production in Tropical and Sub-Tropical Regions with Reference to Northeast Brazil and the Countries of the Caribbean, Central America, and South America (Ed. M. Shelton and E. A. P. Figueiredo). Davis, CA, pp. 79-95.

Kahindi, R. K., S. A. Abdulrazak and R. W. Muinga. 2007. Effect of supplementing Napier grass (Pennisetum purpureum) with Madras thorn (Pithecellobium dulce) on intake, digestibility and live weight gains of growing goats. Small Rumin. Res. 69:83-87.

Kalita, P., P. K. Mukhopadhyay and A. K. Mukherjee. 2007. Evaluation of the nutritional quality of four unexplored aquatic weeds from northeast India for formulation of cost-effective fish feeds. Food Chem. 103:204-209.

Kenji, L., N. Kobayashi, H. Kohno, A. Miyamoto and Y. Fukui. 2004. A comparative study of induction of estrus and ovulation by three different intravaginal devices in ewes during the nonbreeding season. J. Reprod. Dev. 50:63-65.

Khan, M. J., H. Steingass and W. Drochner. 2002. Evaluation of some aquatic plants from Bangladesh through mineral composition, in vitro gas production and in situ degradation measurements. Asian-Aust. J. Anim. Sci. 15:537-542.

Kozloski, G. V., L. M. Bonnecarrére, L. Cadorin, M. V. Reffatti, and L. Lima. 2006. Intake and digestion by lambs of dwarf elephant grass (Pennisetum purpureum Schum. cv. Mott) hay or hay supplemented with urea and different levels of cracked corn grain. Anim. Feed Sci. Technol. 125:111-122.

Leroy, J. L. M. R., T. Vanholder, B. Mateusen, A. Christophe, G. Opsomer, A. De Kruif, G. Genicot and S. A. Van. 2005. Nonesterified fatty acids on follicular fluid of dairy cows and their effect on development capacity of bovine oocytes in vitro. Reproduction 130:485-495.

Leyva, V., B. C. Buckrell and J. S. Walton. 1998. Regulation of follicular activity and ovulation in ewes by exogenous progestagen. Theriogenology 50:395-416.

Liu, X., Q. Dai and N. C. Rawlings. 2007. Ultrasonographic image attributes of non-ovulatory follicles and follicles with different luteal outcomes in gonadotropin-releasing hormone $(\mathrm{GnRH})$ treated anestrous ewes. Theriogenology 67:957-969.

Lozano, J. M., P. Lonergan, M. P. Bolan and D. O'Callagan. 2003. Influence of nutrition on the effectiveness of superovulation programmes in ewes: effect on oocyte quality and postfertilization development. Reproduction 125:543-553.

Martin, G. B. and S. W. Walkden-Brown. 1995. Nutritional influences on reproduction mature male sheep and goats. J. Reprod. Fertil. 49:437-449.

Martínez, R. R. D. 1999. Comparación de cinco técnicas de campo para detectar preñez en ovejas Pelibuey. Vet. Mex. 30:193-198.

Martínez, R. R. D., Q. L. A. Zarco, G. I. Rubio, L. C. Cruz and M. J. Valencia. 2001. Efectos de los implantes subcutáneos de melatonina y la suplementación alimentaria, sobre la inducción de la actividad ovárica en ovejas Pelibuey durante la época de anestro. Vet. Mex. 32:237-247.

Matsas, D. 1993. Pregnancy examination in goats. In: Society for 
Theriogenology, ed. Theriogenology Handbooks. Caprine I. Blacksburg: American College of Theriogenologists. p. 8.

Mazzarri, G., C. Fuenmayor and Y. C. F. Chicco. 1976. Efecto de diferentes niveles alimenticios sobre el comportamiento reproductivo en ovejas tropicales. Agron. Trop. 26:205-213.

Memon, M. A. and R. S. Ott. 1979. Methods of pregnancy diagnosis in sheep and goats. Cornell Vet. 70:226-231.

Mendoza, A. E. A. 2008. Suplementación de selenio y vitamina E en borregas primerizas y sus efectos en variables reproductivas en periodos de anestro estacional. Tesis de Maestría en Ciencias. Colegio de Postgraduados Campus Montecillo. México.

Mitchell, L. M., M. E. King, F. E. Gebbie, M. J. Ranilla and J. J. Robinson. 1998. Resumption of estrus and ovarian cyclicity during the post-partum period in autumn-lambing ewes is not influenced by age or dietary protein content. J. Anim. Sci. 67:65-72.

Molina, M. P., T. E. T. Sánchez, E. O. F. García, G. A. Martínez, L. Cárdenas, O. J. Peralta, J. L. M. Cordero, A. E. Hizarza and C. M. E. Ortega. 2005. Manipulación de la presencia del cuerpo lúteo en la sincronización del estro en ovejas Dorset. Agrociencia 39:11-18.

Navarrete-Sierra, F. L., A. A. T. Cruz, P. E. I. González, A. R. I. E. Piña, G. J. R. Sanginés, L. V. Toledo and R. J. P. Ugalde. 2008 Efecto de la aplicación de la hormona de crecimiento recombinante sobre la respuesta superovulatoria y la viabilidad embrionaria en ovejas de pelo. Rev. Científica 18:175-179.

NRC. 1985. Nutrient requirements of sheep. The National Academy Press. Washington, DC, USA.

Olorunfemi, T. O. S., F. M. Aderibigbe, B. K. Alese and E. A. Fasakin. 2006. Utilization of duckweed (Lemna paucicostata) in least-cost feed formulation for broiler starter: A linear programming analysis. Inform. Technol. J. 5:166-171.

Ortega, P. A. 1997. Maceración fetal espontánea en una borrega: Hallazgos ultrasónicos y cambios plasmáticos en proteína específica de la preñez ovina b y progesterona. Rev. Biomed. 8:33-36.
Ortega-Pacheco, A., R. Montes-Pérez, J. F. Torres-Acosta, A. Aguilar-Caballero and E. Avalos-Borges. 1999. Diagnóstico de gestación en cabras criollas (Capra hircus) mediante determinación de los niveles sanguíneos de progesterona y ultrasonografía de tiempo real. Rev. Biomed. 10:229-234.

Reimers, T. J. 1984. Laboratory training manual on radioimmunoassay in animal reproduction. FAO/IEAE division, Technical reports series No. 233:85-11.

Restall, B. J., J. T. B. Milton, P. Klong-yutti and S. Kochapakdee. 1990. Pregnancy diagnosis in Thai native goats. Theriogenology 34:313-317.

Rhind, S. M. 1992. Nutrition: it effects on reproductive performance and its hormonal control in female sheep and goats. Progress in sheep and goats research (Chapter 2). CAB international. p. 25.

SAS Institute Inc. 2000. SAS/STAT user's guide: Version 8th edn. SAS Institute Inc., Cary, North Carolina, USA.

Tessena, Z. and R. M. T. Baars. 2004. Chemical composition, in vitro dry matter digestibility and ruminal degradation of Napier grass (Pennisetum purpureum (L.) Schumach.) mixed with different levels of Sesbania sesban (L.) Merr. Anim. Feed Sci. Technol. 117:29-41.

Uribe-Velásquez, L. F., E. Obab and M. L. Souza. 2008. Población folicular y concentraciones plasmáticas de progesterona en ovejas sometidas a diferentes protocolos de sincronización. Arch. Med. Vet. 40:83-88

Van Soest, P. J., J. B. Robertson and B. A. Lewis. 1991. Methods for dietary fiber, neutral detergent fiber and nonstarrch polysaccharides in relation to animal nutrition. Symposium: carbohydrate methodology, metabolism and nutritional implications in dairy cattle. J. Dairy Sci. 74:3583-3597.

Wathes, D. C., D. Roberts, E. Abayasekara and R. J. Aitken. 2007. Polyunsaturated fatty acids in male and female reproduction. Biol. Reprod. 77:190-201.

Zhang, L., C. Q. Yu., M. Chimojo and T. Shao. 2011. Effect of different rates of ethanol additive on fermentation quality of Napiergrass (Pennisetum purpureum). Asian-Aust. J. Anim. Sci. 24:636-642. 